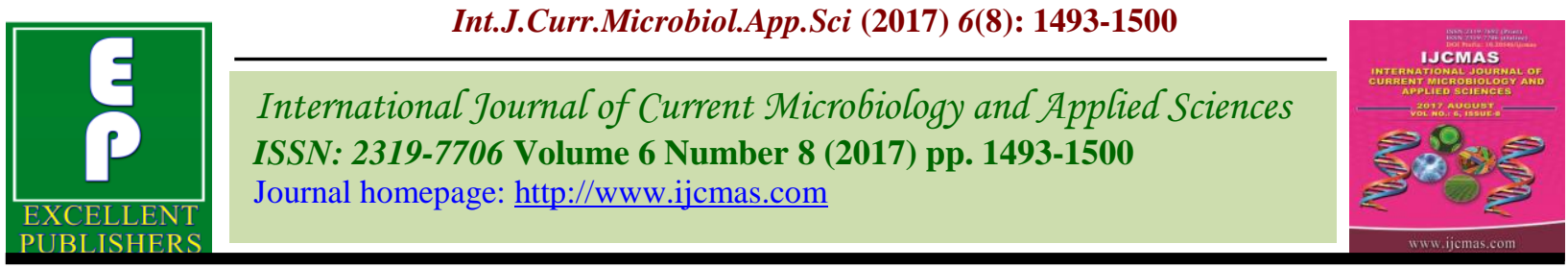

Original Research Article

https://doi.org/10.20546/ijcmas.2017.608.180

\title{
Isolation and Purification of Protein from Skin and Muscles Homogenate of Labeo rohita (Rohu)
}

\author{
Kamal Bijalwan $^{1 *}$, Satish Kumar Verma ${ }^{2}$ and Abhishek Mathur ${ }^{3}$ \\ ${ }^{1}$ Department of Biochemistry, Himalayan University, Arunachal Pradesh, India \\ ${ }^{2}$ K. L. PG College, Allahabad, Uttar Pradesh, India \\ ${ }^{3}$ R\&D cum New product Development, NCFT-EBEC, New Delhi, India \\ *Corresponding author
}

\begin{tabular}{|c|}
\hline Keywords \\
\hline $\begin{array}{l}\text { Antimicrobial } \\
\text { activity, Fresh } \\
\text { water, Labeo } \\
\text { rohita, Protein } \\
\text { fraction. }\end{array}$ \\
\hline Article Info \\
\hline $\begin{array}{l}\text { Accepted: } \\
\text { 17 June } 2017 \\
\text { Available Online: } \\
\text { 10 August } 2017\end{array}$ \\
\hline
\end{tabular}

A B S T R A C T

India is endowed with an extensive network of fisheries resources; a long coast line of $1100 \mathrm{~km}$ along the Arabian Sea, supports a wide range of fish species with economic value and nutritional importance. Approximately 180 species of fish are found in fresh waters of India, majority of which are edible Antimicrobial proteins and peptides had been found from a wide variety of organisms in the last few years. These molecules have attracted much research interest because of their biochemical diversity, broad specificity on antiviral, anti-bacterial, anti-fungi, anti-protozoan parasites, anti-tumoural, and wound-healing effects. Antimicrobial proteins and peptides play key roles in innate immunity. They interact directly with bacteria and kill them. The present study was performed in order to isolate and purify the protein from skin and muscles homogenate of Labeo rohita (Rohu). Different studies are already performed which showed that bacteria and virus have caused high mortality in Labeo rohita cultures, but the endogenous antimicrobial peptides and proteins have not been explored till yet or less evidences are reported. As per the results observed, an antimicrobial component was obtained from the skin and muscles homogenate of $L$. rohita. It was observed that when the skin and muscles homogenate was digested with trypsin (proteolytic enzyme), its antimicrobial activity was lost, which confirmed that the antimicrobial component is a protein. The antimicrobial protein was further purified from the skin and muscles homogenate of Labeo rohita by successive ionexchange and gel filtration chromatography. The protein isolated was demonstrated to be single protein band by SDS-PAGE, with the apparent molecular weight of $46 \mathrm{KDa}$. The crude protein content in the mixed homogenate of the fish was found to be $20.5 \%$. Although different feed content may also vary the nutritional significance of different biomolecules in the fish which is also another part of study. The protein fraction isolated was evaluated for antimicrobial activity. The protein fraction exhibited antimicrobial activity both for the Gram-positive bacteria, Staphylococcus aureus, Micrococcus luteus and Bacillus subtilis, and for the Gram-negative bacteria, Vibrio alginolyticus, Vibrio parahaemolyticus, Vibrio fluvialis, Pasteurella multocida, Aeromonas hydrophila, Escherichia coli, and Pseudomonas aeruginosa. Except A. hydrophila, P. aeruginosa, and E. coli $(\mathrm{MIC}>19 \mathrm{~mol} / \mathrm{L})$, most of the tested Gram-negative bacteria were sensitive to protein fraction $(\mathrm{MIC}<18 \mathrm{~mol} / \mathrm{L})$. Interestingly, the protein fraction showed potent antimicrobial activity against Gram-positive bacteria, S. aureus (MIC 5-10 mol/L) but comparatively weak antimicrobial activity against $M$. luteus and $B$. subtilis. The study thus suggests the presence of antimicrobial amino acids in the protein fraction which are needed to be isolated and characterization for further studies. 


\section{Introduction}

Fish meat possesses high nutritional quality and is therefore a particularly recommended human dietary component. Information concerning the chemical and fatty acid composition of freshwater fishes is valuable to nutritionists who are interested in finding sources of low-fat, high protein foods, with desirable fatty acid compositions and acceptable amount of total cholesterol. Fish meat contains biologically active protein which is characterized by a very favorable composition of amino acids, a high omega-3 polyunsaturated fatty acid content such as eicosapentaenoic acid (20:5 n-3, EPA) and docosahexaenoic (22:6 n-3, DHA), and fatsoluble vitamins as well as it represents a good source of micro- and macro-elements. Antimicrobial proteins and peptides were obtained from a wide variety of organisms. These molecules have attracted much research interest because of their biochemical diversity, broad specificity on anti-viral, antibacterial, anti-fungi, anti-protozoan parasites, and even anti-tumoural or wound-healing effects (Zasloff, 1987; 2002). Compounds with broad antimicrobial activities are thought to be especially important for fish, as their adaptive immune system is structurally simpler than that of mammals or amphibians, and is not fully effective in young fry or at low environmental temperature (Silphaduang and Noga, 2001). The skin epithelium and other mucosal surfaces of fish are rich in antimicrobial peptides (Bergsson et al., 2005). The present study is in need to determine the important nutritional components present in fish, Labeo rohita (Rohu) as most of the population of India residing near the banks of the rivers and specific communities utilizes fish as their regular diet. The study was performed to focus on the nutritional and pharmacological components of fish which makes the fish as an important nutritional and dietary supplement. The study was performed to isolate and determine the antimicrobial nature of the protein in skin and muscles homogenate of Labeo rohita.

\section{Materials and Methods}

\section{Collection of samples}

Sampling of farm cultivated and river water, Labeo rohita (Rohu) fish species was performed for the comparison of fatty acid composition from Doiwala region of Dehradun (U.K).

\section{Preparation of grouper skin homogenate}

Healthy individuals of Labeo rohita (weight range 500-600 g) were procured. The individuals were killed by stabbing the brain with a sterilized knife, after $12 \mathrm{~h}$. Their scales were scraped gently and skins were peeled and washed in $50 \mathrm{mMol} / \mathrm{L}$ Tris- $\mathrm{HCl}$ buffer (pH 7.8, containing $5 \mathrm{mMol} / \mathrm{L}$ EDTA and 0.1 $\mathrm{mol} / \mathrm{L} \mathrm{NaCl}$ ). The skins and muscles were immersed immediately in liquid nitrogen. Then, the frozen skins and muscles were ground into powder with a mortar and pestle under liquid nitrogen, and homogenized in the same buffer. The homogenate was centrifuged at $15,000 \mathrm{~g}$ for $30 \mathrm{~min}$. The supernatant was collected, lyophilized and stored in $-80^{\circ} \mathrm{C}$ until use.

Purification of antimicrobial protein from skin and muscles homogenate of Labeo rohita

The skin and muscles homogenate was purified by ion exchange chromatogram and gel filtration chromatogram. Briefly, the lyophilized skin homogenate was dissolved in $20 \mathrm{~mL} 50 \mathrm{mMol} / \mathrm{L}$ Tris- $\mathrm{HCl} \quad(\mathrm{pH} \quad 7.8$, containing $5 \mathrm{mMol} / \mathrm{L}$ EDTA) and dialyzed against the same buffer for $24 \mathrm{~h}$ at $4^{\circ} \mathrm{C}$ (The molecular weight cut-off of the dialysis tubing was $3,500 \mathrm{D})$. Then, the sample was 
loaded in DEAE-Sephadex A-50 ion exchange column $(2.6 \mathrm{~cm} \times 30 \mathrm{~cm})$. The elution was performed at a flow rate of 30 $\mathrm{mL} / \mathrm{h}$ with a linear $\mathrm{NaCl}$ gradient. The fractions were lyophilized and applied to a Sephadex G-75 (superfine) column $(2.6 \mathrm{~cm}$ $\times 100 \mathrm{~cm}$ ) equilibrated with $50 \mathrm{mMol} / \mathrm{L}$ Tris$\mathrm{HCl}(\mathrm{pH} 7.5$, containing $5 \mathrm{mMol} / \mathrm{L}$ EDTA and $0.1 \mathrm{~mol} / \mathrm{L} \mathrm{NaCl}$ ). Elution was achieved with the same buffer at a flow rate of $9 \mathrm{~mL} / \mathrm{h}$, collecting fractions of $3 \mathrm{~mL}$ per tube. The protein fractions was collected, dialyzed against $50 \mathrm{mMol} / \mathrm{L}$ Tris- $\mathrm{HCl} \quad(\mathrm{pH} \quad 8.8$, containing $5 \mathrm{mMol} / \mathrm{L}$ EDTA) for $24 \mathrm{~h}$ at $4^{\circ} \mathrm{C}$, and loaded on a Q-Sepharose (high performance $)$ column $(2.6 \mathrm{~cm} \times 30 \mathrm{~cm})$ preequilibrated with the same buffer. A linear $\mathrm{NaCl}$ gradient of $0-0.5 \mathrm{~mol} / \mathrm{L}$ was employed to elute the proteins. The elution was performed at a flow rate of $30 \mathrm{~mL} / \mathrm{h}$ with a linear $\mathrm{NaCl}$ gradient, collecting fractions with antimicrobial activity of $5 \mathrm{~mL}$ per tube.

\section{Protein concentration}

The protein concentration was determined by the Lowry method according to the procedure described (Gerhardt et al., 1994). In this procedure, the proteins were first pretreated with copper ions in an alkali solution. The aromatic amino acids in the treated sample reduced the phosphomolybdicphosphotungstic acid present in the Folin's reagent. Since the endpoint of the reaction has a blue color, the amount of protein in the sample could be estimated by reading the absorbance using a spectrophotometer (Systronics- UV-VIS spectrophometer) at 750 nm.

\section{Electrophoretic studies}

SDS-PAGE was performed as reported by Laemmli (1970). For SDS-PAGE, samples were pretreated in $2.5 \%$ SDS alone (nonreducing conditions) or in $2.5 \%$ SDS and
5\% mercapto ethanol (reducing conditions) for 5 minutes at $100^{\circ} \mathrm{C}$. Gels were stained with $0.1 \%$ Coomassie brilliant blue R-250.

\section{Antimicrobial assays}

Different bacterial strains were selected for this study, Gram-negative bacteria including Vibrio alginolyticus, Vibrio parahaemolyticus, Pasteurella multocida, Vibrio fluvialis, Aeromonas hydrophila, Escherichia coli and Pseudomonas aeruginosa and Gram-positive bacteria including Staphylococcus aureus, Micrococcus luteus and Bacillus subtilis. Strains were grown on broth nutrient medium. Antimicrobial activity was monitored by a liquid growth inhibition assay. Briefly, logarithmic phase bacterial cultures were diluted in the broth $[1 \%(\mathrm{w} / \mathrm{v})$ bacteriotryptone, $0.9 \%(\mathrm{w} / \mathrm{v}) \mathrm{NaCl}$ ] to an $\mathrm{A}_{600}$ of 0.001 , which is approximately equivalent to $10^{5} \mathrm{CFU} / \mathrm{ml}$. Diluted bacteria $(90 \mu \mathrm{L})$ were mixed with $10 \mu \mathrm{L}$ of either water (control) or purified protein in wells of a micro-titration plate. After overnight incubation at $25^{\circ} \mathrm{C}$, the bacterial growth was monitored by measuring the change in the absorbance of the culture with a microplate reader at $600 \mathrm{~nm}$ (Casteels et al., 1993).

\section{Determination of the minimum inhibitory concentration (MIC)}

The minimum inhibitory concentration (MIC) of the antimicrobial protein was determined as follows. Briefly, bacteria were incubated in Todd Hewitt broth [50\% (w/v) beef heart infusion; $2 \%(\mathrm{w} / \mathrm{v})$ peptic digest of animal tissue; $0.2 \%(\mathrm{w} / \mathrm{v})$ dextrose; $0.2 \% \quad(\mathrm{w} / \mathrm{v})$ $\mathrm{NaCl} ; 0.04 \%$ (w/v) $\quad \mathrm{Na}_{2} \mathrm{HPO}_{4} ; 0.25$ (w/v) $\left.\mathrm{Na}_{2} \mathrm{CO}_{3}\right]$ in the presence of 2-fold serial dilutions of sample (final concentration $1.25-80 \mu \mathrm{Mol} / \mathrm{L}$ ). Bacterial growth was monitored by a liquid growth inhibition assay. MIC was expressed as a range of the highest 
concentration of purified protein at which bacteria were able to grow and the lowest concentration that the bacterial growth was completely inhibited. All assays were performed in duplicate (Lauth et al., 2002).

\section{Proteolytic digestion of homogenate}

Susceptibility of the antimicrobial activity of crude skin and muscles homogenate to proteolytic digestion was determined by incubation of $4.5 \mathrm{mg}$ skin homogenate (containing $1 \mathrm{mg}$ proteins) with $250 \mu \mathrm{g} / \mathrm{L}$ crystalline trypsin for 60 minutes at $37^{\circ} \mathrm{C}$. Antimicrobial activities of the skin and muscles homogenate before and after protease (trypsin) treatment against the similar bacterial cultures were determined.

\section{Results and Discussion}

The present study suggested the isolation and separation of protein from skin and muscles homogenate by centrifugation (Figure 1). Further the proteins were purified via ionexchange and gel chromatography (Figure 2). The molecular weight of the protein fraction isolated and purified was determined. The concentration of the purified protein was determined as $20.5 \%$ of the total skin and muscles homogenate prepared as determined by quantitative method. The results of the electrophoretogram showed the molecular weight of the protein as $46 \mathrm{KDa}$ (Figure 3).

The antimicrobial activity of the protein was determined against Vibrio alginolyticus, Vibrio parahaemolyticus, Pasteurella multocida, Vibrio fluvialis, Aeromonas hydrophila, Escherichia coli, Pseudomonas aeruginosa, Staphylococcus aureus, Micrococcus luteus and Bacillus subtilis at $500 \mathrm{mg} / \mathrm{ml}$. The results were found to be very surprising as the protein fraction was found to have antibacterial activity against most of the pathogens studied.

The results follows the order viz. $V$. parahaemolyticus $(56.0 \mathrm{~mm})>P$. multocida $(48.0 \mathrm{~mm})>V$. alginolyticus $(45.0 \mathrm{~mm})>S$. aureus $(42.0 \mathrm{~mm})>V$. fluvialis $(38.7 \mathrm{~mm})>$ M. luteus $(21.0 \mathrm{~mm})>$ B. subtilis $(18.5 \mathrm{~mm})$. No antibacterial activity was found against $A$. hydrophila, E. coli and $P$. aeruginosa. It was also observed that, when treated the results are shown in table 1 and figure 4 (a); (b). The results of MIC are shown in table 2 and figure 5.

Table.1 Antimicrobial activity of protein fraction purified as such and Protein fraction treated with trypsin

\begin{tabular}{|c|c|c|c|c|c|c|c|c|c|c|}
\hline Protein fraction purified & \multicolumn{5}{|c|}{ Diameter of zone of inhibition (mm) against pathogens } \\
\hline Protein fraction purified $\mathbf{5 0 0} \mathbf{~ m g} / \mathbf{m l})$ & VA & VPH & PM & VF & AH & ECO & PA & SA & ML & BS \\
\hline Protein fraction purified after treatment with trypsin & NA & NA & NA & NA & NA & NA & NA & NA & NA & NA \\
\hline
\end{tabular}

*V. alginolyticus (VA), V. parahaemolyticus, (VPH) P. multocida (PM), V. fluvialis (VF), A. hydrophila (AH), E. coli (ECO) and P. aeruginosa (PA), S. aureus (SA), M. luteus (ML) and B. subtilis (BS); NA, No activity

Table.2 MIC of protein fraction purified as such and protein fraction treated with trypsin

\begin{tabular}{|c|c|c|c|c|c|c|c|c|c|c|}
\hline Protein fraction purified & \multicolumn{9}{|c|}{ MIC (mol/liter) } \\
\hline Protein fraction purified & VA & VPH & PM & VF & AH & ECO & PA & SA & ML & BS \\
\hline $\begin{array}{c}\text { Protein fraction purified after treatment } \\
\text { with trypsin }\end{array}$ & NA & NA & NA & NA & NA & NA & NA & NA & NA & NA \\
\hline
\end{tabular}

*V. alginolyticus (VA), V. parahaemolyticus, (VPH) P. multocida (PM), V. fluvialis (VF), A. hydrophila (AH), E. coli (ECO) and P. aeruginosa (PA), S. aureus (SA), M. luteus (ML) and B. subtilis (BS) 
Fig.1 Separation of proteins from skin and muscles homogenate of Labeo rohita
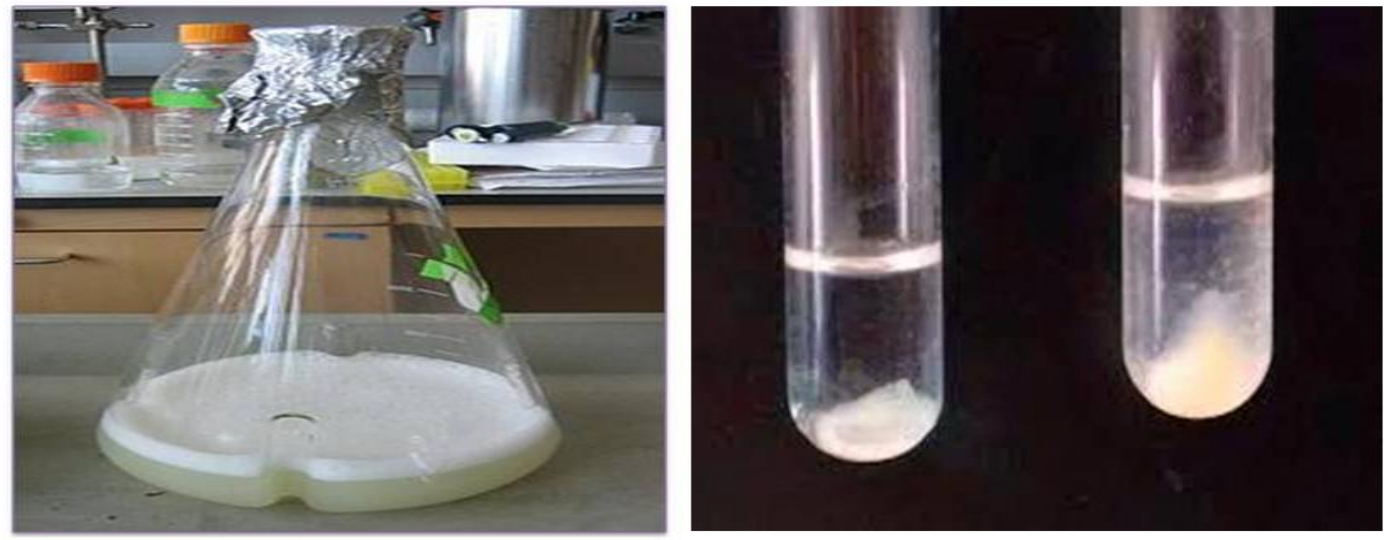

Homogenization and centrifugation of skin and muscles of Labeo rohita

Fig.2 Purification of protein isolated via Ion exchange and Gel chromatography

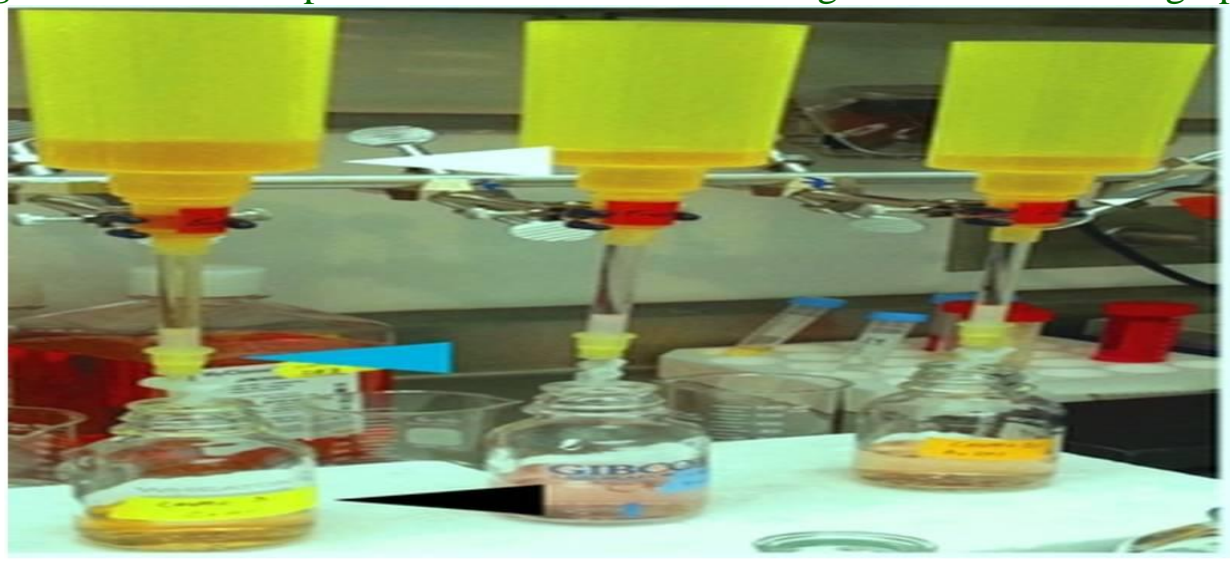

Purification of protein by Ion-exchange and gel chromatography of protein fraction from skin and muscles homogenate of Labeo rohita

Fig.3 SDS PAGE of intact and digested protein

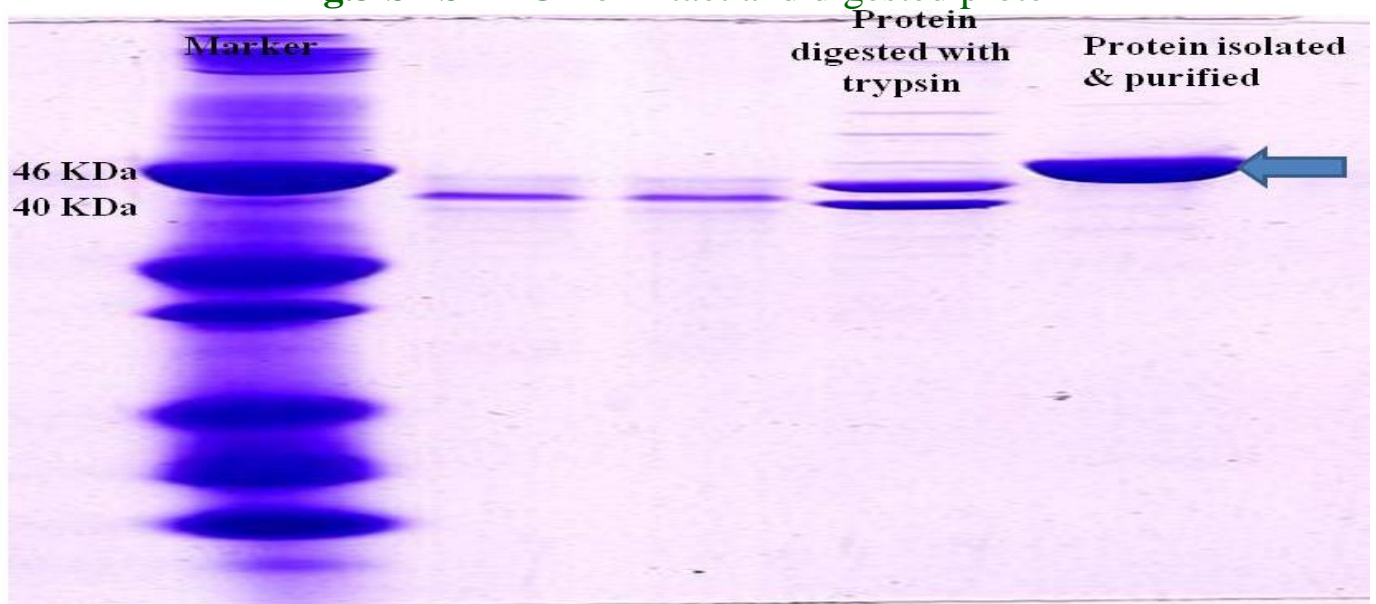

SDS PAGE electrophoretogram of protein purified and protein digested with trypsin 
Fig.4 (a) Graphical representation of antimicrobial activity of protein fraction as such and Protein fraction treated with trypsin

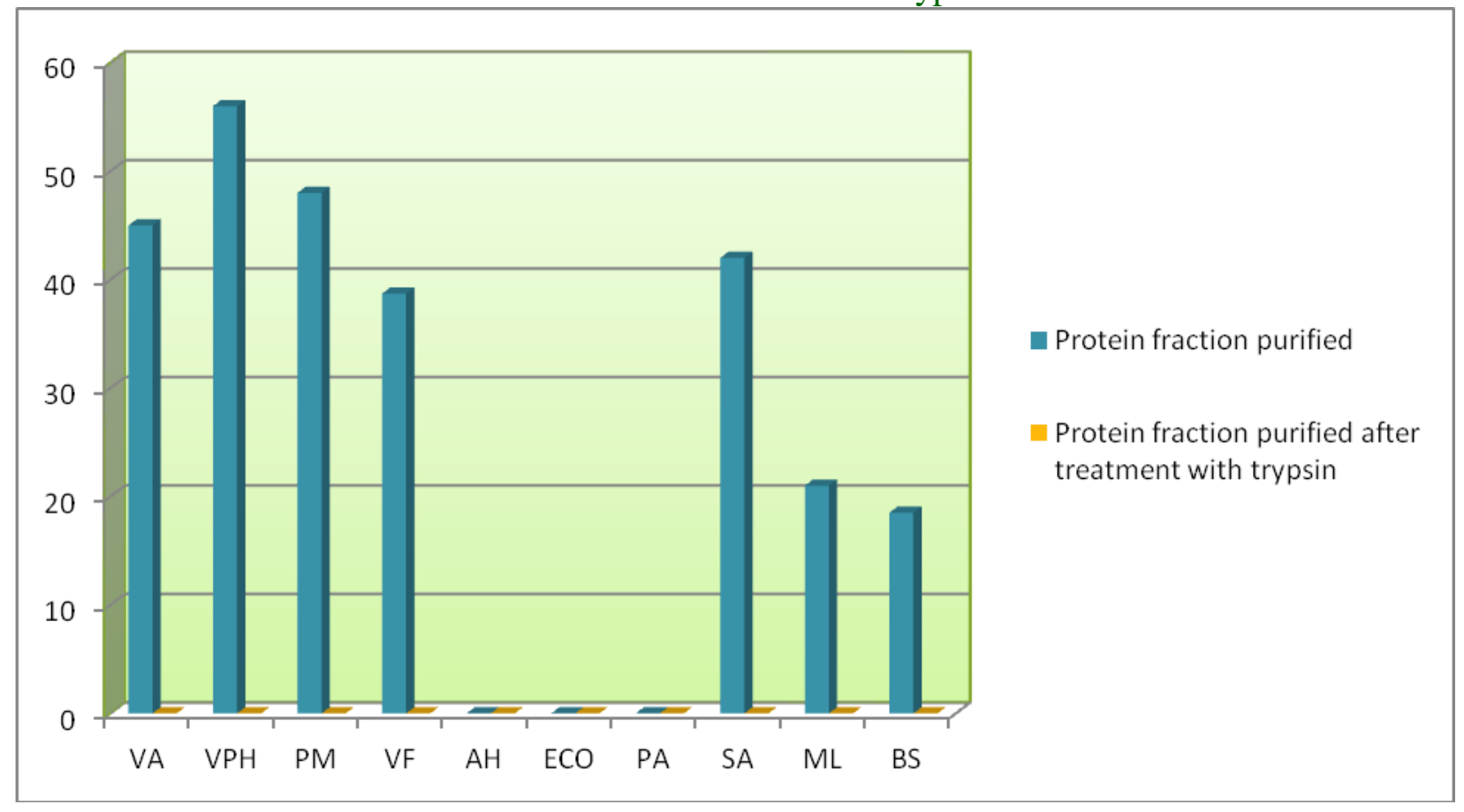

Fig.4 (b) Antimicrobial activity of protein fraction against pathogenic microbes
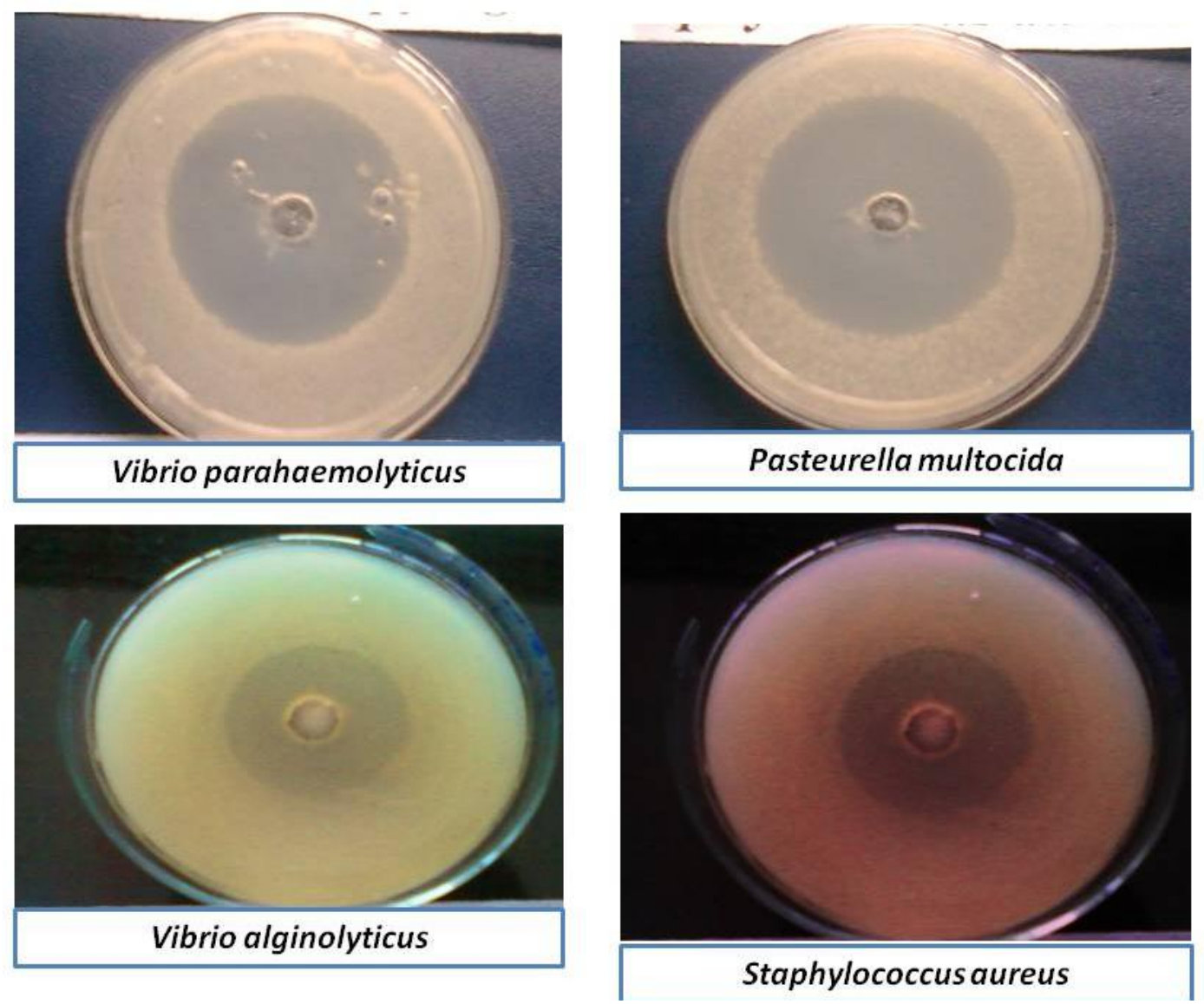

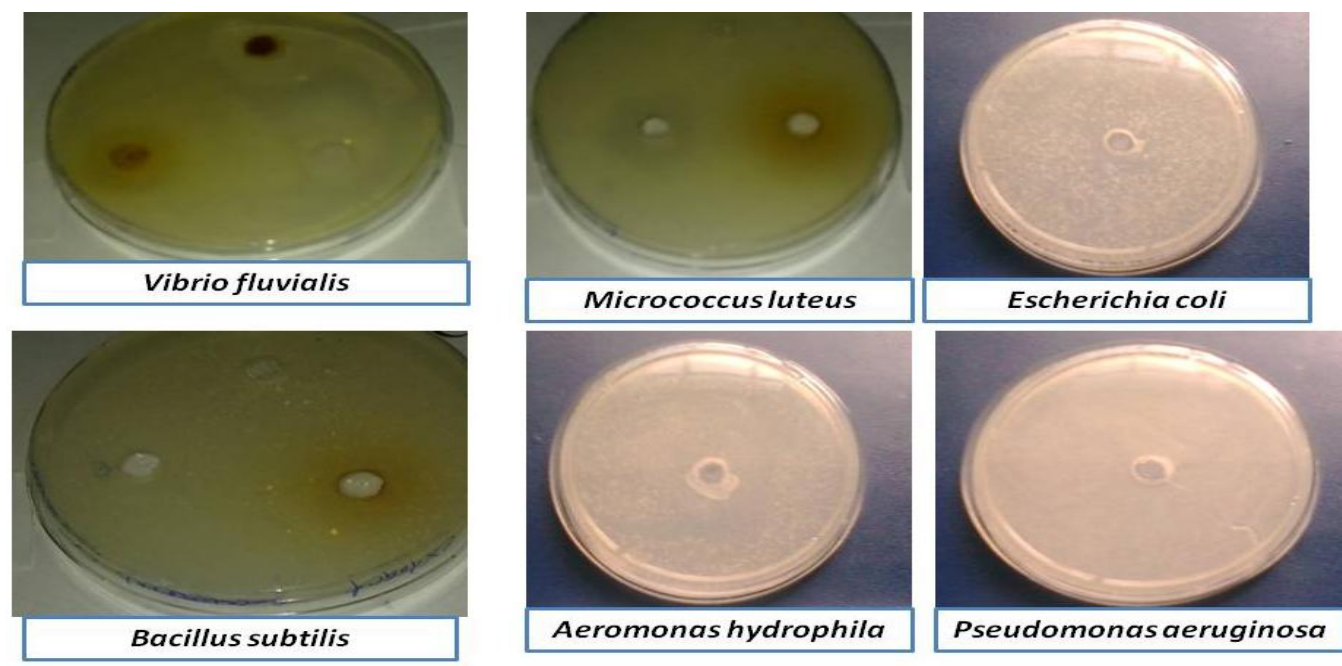

Fig.5 Graphical representation of MIC values of protein fraction as such and Protein fraction treated with trypsin

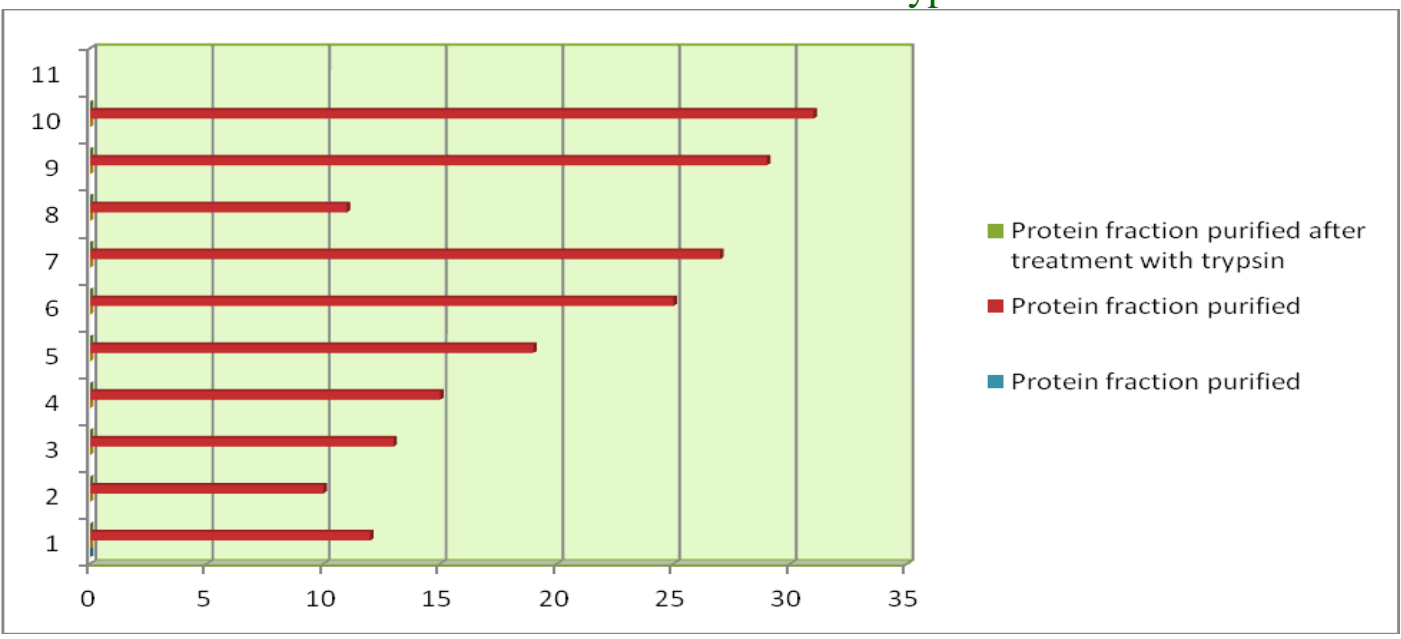

The previous studies on skin mucus describing antimicrobial nature was illustrated (Khondoker et al., 2014). The bactericidal proteins from skin mucus and skin extracts from fresh water fish's viz. Clarias batrachus and Tillapia mossambicus were determined (Ponmanickam et al., 2013). The proteins in Piaractus mesopotamicus (Pacu) were determined as an indicator of innate immunity (Biller-Taka-hashi et al., 2013). Recent studies were performed on Labeo rohita (Rohu) after exposure to phenolic compounds (Gaur et al., 2016a; 2017b).

The study thus suggests the presence of antimicrobial amino acids in the protein fraction of Labeo rohita which are needed to be isolated and characterized for further studies. The present study suggests that, the protein is most efficient antimicrobial agent against dreadful pathogens. The study provides a path for exploration of such antimicrobial agents from such fresh water fishes and other aquatic fauna.

\section{References}

Bergsson G, Agerberth B, Jörnvall H, Gudmundsson GH. 2005. Isolation and identification of antimicrobial components from the epidermal mucus 
of Atlantic cod (Gadus morhua). FEBS $J, 272$ (19): 4960-4969.

Biller-Takahashi JD, Takahashi LS, Pilarski F, Sebastião FA, Urbinati EC. 2013. Serum bactericidal activity as indicator of innate immunity in pacu, Piaractus mesopotamicus (Holmberg, 1887). Arq. Bras. Med. Vet. Zootec., 65 (6): 1745-1751

Casteels P, Ampe C, Jacobs F, Tempst P. 1993. Functional and chemical characterization of Hymenoptaecin, an antimicrobial polypeptide that is infection-inducible in the honeybee (Apis mellifera). J Biol Chem., 268, 7044-7054.

Gaur V, Raina V, Jain R, Mathur A. 2016. Proceedings of International Conference on Recent Advances in Biotechnology \& Nano biotechnology (Int-BIONANO-2016), pp. 101-115.

Gaur V, Mathur A. 2017. Evaluation of antioxidant profile of Labeo rohita in stress condition after exposure to phenolic compounds. Int. J. Sci. Res. Pub., 7(6): 423-434.

Gerhardt P, Murray RGE, Wood WA, Krieg NR 1994. Methods for general and molecular bacteriology, ASM Washington DC, 518

Khondoker S, Islam MM, Hossain MM, Islam M, Khatun MA. 2014. Competitive antibacterial activity of two Indian major carps and two Chinese carps fish mucus against common pathogenic bacteria at aquaculture pond. Int. J. Fish. Aq. Studies, 2(2): 158-162.

Lauth X, Shike H, Burns JC, Westerman ME, Ostland VE, Carlberg JM, Van Olst JC, Nizet V, Taylor SW, Shimizu C, Bulet P. 2002. Discovery and characterization of two isoforms of moronecidin, a novel antimicrobial peptide from hybrid striped bass $J$ Biol Chem, and 277 (7): 5030-5039.

Laemmli UK. 1970. Cleavage of structural proteins during the assembly of the head of bacteriophage T4. Nature, 227: 680-685.

Ponmanickam P, Rameskumar G, Elavarasi K, Ranjini S, Rajagopal T. 2013. Bactericidal proteins of skin mucus and skin extract from fresh water fishes, Clarias batrachus and Tilapia mossambicus. Thai J. Pharm. Sci., 37: 194-200.

Silphaduang U, Noga EJ. 2001. Antimicrobials: Peptide antibiotics in mast cells of fish. Nature, 414: 268269.

Zasloff M. Magainins. 1987. A class of antimicrobial peptides from Xenopus skin: Isolation, Characterization of two active forms, And partial cDNA sequence of a precursor. Proc. Natl. Acad. Sci. USA, 84, 5449-5453.

Zasloff M. 2002. Antimicrobial peptides of multicellular organisms. Nature, 415, 389-395.

\section{How to cite this article:}

Kamal Bijalwan, Satish Kumar Verma and Abhishek Mathur. 2017. Isolation and Purification of Protein from Skin and Muscles Homogenate of Labeo rohita (Rohu). Int.J.Curr.Microbiol.App.Sci. 6(8): 1493-1500. doi: https://doi.org/10.20546/ijcmas.2017.608.180 